\title{
Effect of steroid hormones on tissue remodelling and progesterone receptors in the uterus of seasonally anoestrous brushtail possums (Trichosurus vulpecula)
}

\author{
R J Sizemore ${ }^{1}$, P R Hurst ${ }^{1}$ and B J McLeod ${ }^{1,2}$ \\ ${ }^{1}$ Department of Anatomy and Structural Biology, School of Medical Sciences, University of Otago, PO Box 56, \\ Dunedin, New Zealand and ${ }^{2}$ AgResearch, Private Bag 50034, Mosgiel, Dunedin, New Zealand \\ Correspondence should be addressed to P R Hurst; Email: Peter.Hurst@stonebow.otago.ac.nz
}

\begin{abstract}
This study describes progesterone receptor (PR) location within uterine cells and associated morphological changes to the uterine luminal and glandular epithelium in seasonally anoestrous brushtail possums treated with oestradiol and/or progesterone.

Twenty-four adult female possums ( $n=6$ /group) were treated with oestradiol, progesterone, oestradiol followed by progesterone or with the oil vehicle alone for 6-day periods. Uterine tissue was recovered, weighed and processed for light and transmission electron microscopy and for immunohistochemistry for PRs. Stereological techniques were used to quantify epithelial cell and constituent volumes for both luminal and glandular tissues. Plasma concentrations of oestradiol and progesterone were determined by radioimmunoassay.

Mean uterine wet weights were significantly heavier $(P<0.001)$ following oestradiol/progesterone treatment and maximum gland dilation, cellular and stromal growth, maximum cell height, and cell and constituent volumes were recorded after this treatment regimen. Cell nuclei and debris were commonly observed in gland lumina, and nuclear PRs were found predominantly in stromal cells following oestradiol-only treatment. Sequential treatment with oestradiol and then progesterone caused a decline in the number of positively stained cells. Epithelial cells contained extensive secretory organelles and degenerating cells were common within the glands.

Oestradiol treatment induced cell and cell constituent growth and promoted PR formation in anoestrous possum uterine tissue. Subsequent exposure to progesterone stimulated uterine tissues to reach maximum wet weights and led to the cellular maturation necessary to remodel the uterus in preparation for pregnancy.

Reproduction (2004) 127 255-264
\end{abstract}

\section{Introduction}

The female brushtail possum (Trichosurus vulpecula) is a monovular, seasonally polyoestrous marsupial (Pilton \& Sharman 1962, Kean et al. 1964) with an oestrous cycle of 24-26 days (Shorey \& Hughes 1973, Tyndale-Biscoe 1984). The female reproductive tract has two separate uteri, each with its own cervix (Kean et al. 1964). At a cellular level, the uterus consists of an inner endometrium comprising a luminal epithelium, glands and connective tissue, and an underlying myometrium that includes circular, oblique and longitudinal muscle fibres (Kean et al. 1964). Within the endometrium, the glands are continuous with the luminal epithelium and both luminal and glandular tissues are composed of ciliated (pale cytoplasmic cells) and secretory (dark cytoplasmic cells) epithelial cells (Shorey \& Hughes 1973, Shaw 1996).

In New Zealand, the possum breeding season extends from March to November, with an intervening period of seasonal anoestrus (Kean et al. 1964, McLeod et al. 1999). During anoestrus, all reproductive structures including the uteri are small in size and pale in colour (Kean et al. 1964). During the oestrous cycle, the uterus undergoes extensive morphological and histological changes (Pilton \& Sharman 1962, Kean et al. 1964, Shorey \& Hughes 1972, 1973, Arnold \& Shorey 1985, Curlewis \& Stone 1986). Uteri in both pregnant and non-pregnant possums undergo significant linear weight increases to reach their maximum size early in the luteal phase, at which time they are highly oedematous and vascular (Curlewis \& 
Stone 1986, Crawford et al. 1997). During the mid-luteal phase, the thickness of the endometrium reaches its maximum (Shorey \& Hughes 1973) and this parallels uterine weight increases (Curlewis \& Stone 1986, Crawford et al. 1997). The height of both luminal and glandular epithelial cells, and the proportion of ciliated or secretory cells, change throughout the oestrous cycle, depending on the activity of the cell and storage of secretory products, which is related to circulating concentrations of oestradiol and progesterone (Shorey \& Hughes 1972, 1973, Brenner \& West 1975). Luminal and glandular epithelial cell height increases in response to oestradiol, although glandular epithelium reaches maximum height during the luteal phase when progesterone is predominant (Shorey \& Hughes 1973). During this stage of the cycle, the basal regions of the glands secrete 'uterine' milk via apocrine and holocrine secretion. Cruz \& Selwood (1997) have also shown growth of the uterine wall and noted increased epithelial cell height during the early stages of pregnancy in the dunnart, Sminthopsis macroura.

The actions of the steroid hormones are thought to be mediated through binding to steroid receptors (Milgrom et al. 1973) which exist as two distinct sub-types $\alpha$ and $\beta$ (Saunders 1998, Conneely et al. 2002). Therefore, the impact of steroid hormones on uterine tissue is dependent on the availability of receptors, as has been reported in dogs (Vermeirsch et al. 2000a,b). Only a single study, using binding assays and electrophoresis, has previously attempted to describe cytosolic steroid receptor concentrations in the brushtail possum (Curlewis \& Stone 1986). Both oestradiol receptor (ER) and progesterone receptor (PR) concentrations were high at the time of oestrus, but had declined by the mid-luteal phase. This decrease was due to either a negative effect of progesterone on receptor synthesis, or to the steroid-receptor complex being relocated into the nucleus (Brenner \& West 1975). In the tammar wallaby (Macropus eugenii) uterine steroid receptors were studied in quiescent animals and also in gravid and non-gravid uteri (Renfree \& Blanden 2000). Both PR and ER concentrations were high in quiescent samples and during the early phase of pregnancy. However, in the latter stages of pregnancy, the levels reduced but the ER concentrations differed in the two uteri suggesting unilateral effects of the conceptus and or corpus luteum become increasingly important as parturition approaches.

Recent immunohistological studies have shown steroid receptors to be located within cell nuclei of human and canine uteri (Lessey et al. 1988, Vermeirsch et al. $2000 a, b)$. Oestradiol is known to increase steroid receptor numbers, while progesterone down-regulates steroid receptors (Brenner \& West 1975). In the canine uterus, the stroma and myometrium contain more cells that were positive for steroid receptors and their staining intensity was apparently greater, suggesting that these cell types were more sensitive to steroid hormones and are possibly more important in mediating hormonal signals to other uterine cell types (Pekonen et al. 1988, Nelson et al. 1991, Vermeirsch et al. 2000a,b).

In possums during anoestrus, there is no embryonic diapause and both uteri are small and likely to be functionally dormant. We were interested to determine if external administration of steroids by way of subcutaneous implants could stimulate uterine growth, development of the endometrium and induction of PRs during anoestrus.

\section{Materials and Methods Animals and management}

Adult female brushtail possums (Trichosurus vulpecula), captured locally within the Otago region of New Zealand (latitude $45^{\circ} \mathrm{S}$ ), were housed as groups at the AgResearch Invermay possum facility (McLeod et al. 1997). Animals were fed fresh fruit and cereal-based pellets, with water available ad libitum and Pinus radiata branches were provided as a source of browse. Housing of possums and all experimental procedures had been approved by the AgResearch Invermay Animals Ethics Committee according to the Animal Welfare Act 1999.

\section{Experimental design}

In mid-seasonal anoestrus (January), 24 adult female possums were randomly allocated to four experimental groups ( $n=6 /$ group). Treatment involved exposure to Silastic implants that contained either oestradiol- $17 \beta$, progesterone or the oil vehicle alone. Implants were made from laboratory grade Silastic tubing $(25 \mathrm{~mm}$ : internal diameter $3.35 \mathrm{~mm}$, outside diameter $4.65 \mathrm{~mm}$; Dow Corning, Midland, MI, USA) and contained $0.125 \mathrm{mg}$ oestradiol- $17 \beta$ or $0.125 \mathrm{mg}$ progesterone (Sigma, St Louis, MO, USA) in $0.2 \mathrm{ml}$ sesame oil. The implants were left in situ for a period of 6 days (oestradiol or progesterone or oil vehicle) or for two successive 6-day periods (oestradiol followed by progesterone).

For implant insertion and removal, the possums were anaesthetised by halothane inhalation (Fluothane; Zeneca Pharmaceuticals Ltd, Macclesfield, Cheshire, UK), the area between the shoulder blades was clipped, scrubbed with isopropyl alcohol and the site injected with local anaesthetic $(0.3 \mathrm{ml}$ lignocane hydrochloride $2 \%(\mathrm{w} / \mathrm{v})$; Virbec Laboratories, Auckland, NZ). The implant was inserted into a subcutaneous pocket and the incision closed with a single suture. The site was treated with a topical dressing (Negasunt antibiotic powder; Bayer NZ Ltd, Glenfield, Auckland, NZ) and the animal injected with a long-acting antibiotic $(0.5 \mathrm{ml}$ Penodure S; Boehringer Ingelheim, Auckland, NZ). Animals being treated with both steroids had their oestradiol implants removed after 6 days and replaced with progesterone implants, following the same procedure. All possums were weighed at the 
time of implant insertion and were checked 2 and 4 days later to ensure that the implants had remained in situ.

\section{Tissue collection and preparation}

Animals were anaesthetised by halothane inhalation and weighed. A blood sample $(10 \mathrm{ml})$ was taken via cardiac puncture using a heparinised vacutainer $(\mathrm{BD}$, Rutherford, $\mathrm{NJ}$, USA). Plasma samples were stored at $-20^{\circ} \mathrm{C}$ until assayed for progesterone and oestrogen content. Animals were then killed by intra-cardiac injection of barbiturate ( $2 \mathrm{ml}$ euthal; Delta Veterinary Laboratories Pty Ltd, Somersby, NSW, Australia). The reproductive tract was removed and the uteri dissected and weighed. One uterus was dissected into approximately $5 \mathrm{~mm}^{2}$ pieces, snap-frozen in liquid nitrogen and stored at $-80^{\circ} \mathrm{C}$; this tissue sample, which included myometrium, was not used in this study. The other uterus was dissected longitudinally to expose the mucosal surface and cut into approximately $5 \mathrm{~mm}^{2}$ pieces, half of which were prepared for light microscopy (LM) and immunohistochemistry and half were processed for transmission electron microscopy (TEM).

\section{Hormone assays}

Plasma progesterone concentrations were determined using a coated-tube radioimmunoassay kit (DSL-3900; Diagnostic Systems Laboratories Inc., Webster, TX, USA). Within this study, the limit of sensitivity was $0.2 \mathrm{ng} / \mathrm{ml}$ and the intra-assay coefficient of variation $<10 \%$. Plasma oestradiol concentrations were determined by a doubleantibody radioimmunoassay (Lun et al. 1998), previously adapted for possum plasma (Mahoney et al. 2003). The intra-assay coefficient of variation was $<6 \%$ and the limit of detection was $0.5 \mathrm{pg} / \mathrm{ml}$. Serial dilutions of high concentration possum control sera ran parallel to the standard curve for both steroid hormones.

\section{LM and TEM}

For LM, tissue was immersion-fixed in $4 \%$ paraformaldehyde in phosphate-buffered saline (PBS) for $17 \mathrm{~h}$ and then stored in $70 \%$ alcohol at $4{ }^{\circ} \mathrm{C}$. Tissue was dehydrated through graded alcohol washes $(70-100 \%$ concentration), infiltrated and embedded in paraffin wax and $4 \mu \mathrm{m}$ sections were stained with Harris haematoxylin and $0.5 \%$ eosin.

For TEM, $3 \mathrm{~mm}^{3}$ pieces of tissue were immersion-fixed in $2 \%$ glutaraldehyde in $0.1 \mathrm{M}$ PBS buffer at $4{ }^{\circ} \mathrm{C}$ for $17 \mathrm{~h}$ and post-fixed in $1 \%$ osmium tetroxide in $0.1 \mathrm{M}$ PBS for $1 \mathrm{~h}$. Tissue was block-stained in $1 \%$ uranyl acetate in $0.1 \mathrm{M}$ sodium hydrogen maleate buffer for $1 \mathrm{~h}$ at $4{ }^{\circ} \mathrm{C}$ and dehydrated in a graded series $(50-100 \%)$ of ethanol washes, rinsed in propylene oxide, infiltrated with propylene oxide and epoxy resin (Agar 100 resin; Agar Scientific Ltd, Stansted, Essex, UK) and embedded in epoxy resin. Semi-thin sections $(1-2 \mu \mathrm{m})$ were cut, stained with methylene blue $(1 \%$ methylene blue,
$1 \%$ azur, $1 \%$ borax) and viewed under a light microscope to establish that the orientation of the tissue was appropriate and that the mucosal surface was included. Selected blocks were trimmed and thin sections (60$80 \mathrm{~nm}$ ) cut and mounted on formvar-coated, single-slot copper grids and stained in an LKB 2168 ultra-stainer (Bromma, Sweden) using uranyl acetate and lead citrate. Sections were viewed in a Phillips 410 LS transmission electron microscope and photographed.

\section{Immunohistochemistry for PRs}

Tissue samples that had been fixed, blocked and cut as described for LM were subjected to the immunohistochemistry procedure described by Zeps et al. (1999). Sections were de-waxed in xylene, rehydrated and washed in PBS, subjected to antigen retrieval in $5 \mathrm{mM}$ ethyleneglycol-bis-(3-amino-ethyl ether) $\mathrm{N}, \mathrm{N}^{\prime}$ tetra-acetic acid $(\mathrm{pH} 8.0)$ by heating under pressure for $20 \mathrm{~min}$. The tissues were washed in $0.1 \mathrm{M}$ PBS and after endogenous peroxidase was blocked by incubating in $3 \% \mathrm{H}_{2} \mathrm{O}_{2}$ in methanol for $5 \mathrm{~min}$, rinsed sequentially with distilled water and 0.1 M PBS containing $0.2 \%$ Tween 20 .

Non-specific binding sites were blocked by applying goat serum in $0.1 \mathrm{M}$ PBS (Sigma; G9023, 1:20) for $30 \mathrm{~min}$ and washed again in $0.1 \mathrm{M}$ PBS with $0.2 \%$ Tween 20 . Antisera $(60 \mu \mathrm{l}$ polyclonal anti-PR antibody (SC-538; Santa Cruz Biotechnology, Santa Cruz, CA, USA) in dilution buffer, 1:50) was applied to one section on each slide, with an adjacent serial section serving as a negative control, with only goat serum in PBS $(1: 20)$ applied. The antibody reacts with both $\alpha$ and $\beta$ forms of the receptor. Slides carrying sections of 6-week-old mouse uterine horn tissue acted as positive controls. Slides were incubated in a moist chamber for $16 \mathrm{~h}$ at $4{ }^{\circ} \mathrm{C}$, washed three times in $0.1 \mathrm{M}$ PBS with $0.2 \%$ Tween 20 and the secondary antibody (biotinylated goat-anti-rabbit IgG; Amersham Life Science, Amersham, Bucks, UK) in 0.1 M PBS (1:200) was applied for $50 \mathrm{~min}$. After washing $(\times 3)$ in $0.1 \mathrm{M}$ PBS with $0.2 \%$ Tween 20 , streptavidin biotinylated horseradish peroxidase (Amersham Life Science) in 0.1 M PBS (1:100) was applied for $50 \mathrm{~min}$. The slides were again washed $(\times 3)$ in $0.1 \mathrm{M}$ PBS with $0.2 \%$ Tween 20 and 2-amino9-ethlycarbozole (AEC 101, staining kit; Sigma) applied to each section for $8-10 \mathrm{~min}$. The reaction was stopped by immersing in distilled water, rinsed in running water $(5 \mathrm{~min})$ and then counter-stained with Gill no. 1 haematoxylin (5s), cover-slipped with glycerol and sealed with nail varnish. The proportion of cells staining for PRs was estimated by counting the number of positive cells in randomly selected fields of view.

\section{Stereological method}

An unbiased estimation of volume-weighted mean volume of the epithelial cells $(V v)$ was obtained from vertical 
sections (Baddeley et al. 1986, Gundersen et al. 1988) using a method similar to that used previously on possum cul-de-sac tissue (Crawford et al. 1997, Mahoney et al. 2002). This is based on the theory that the probability of a test point intercepting a particle or cell is proportional to the volume of that particle or cell (Baddeley et al. 1986). It involved randomly placing sine-weighted test lines over TEM photographs that each included three to six cell profiles, and measuring the intercept lengths. Between 36 and 72 cells were sampled from tissues of each treatment group, with sampling being repeated twice per image. An estimate of volume $(V v)$ was then obtained by cubing the individual intercept lengths, calculating the mean of these lengths (I) and multiplying this by $\pi / 3$ : that is $V_{v}=\mathrm{I}_{\mathrm{o}}^{3} \cdot \pi / 3$.

Cellular constituent volumes of nuclei, cytoplasm, mitochondria and secretory vesicles were calculated by randomly placing a $20 \mathrm{~mm}^{2}$ point-counting grid over the TEM images and counting the total number of points that hit the cell constituents. Images were sampled three times and the mean percentages of these constituents calculated for both luminal and glandular epithelium from each treatment group (Gundersen \& Jensen 1983). The mean percentages were converted to estimates of volume by multiplying them by their $V v$. The vertical height of each cell sampled was also determined in $\mathrm{mm}$ by measuring the distance from the edge of the basement membrane to the apical membrane. Heights in $\mathrm{mm}$ were converted to real values $(\mu \mathrm{m})$ by adjustment for image magnification.

\section{Statistical analysis}

Data of standardised uterine weights, plasma hormone concentrations, luminal and glandular epithelial cell heights, volumes and constituent volumes, which were normally distributed and homoscadastic, were analysed by one-way ANOVA. Values shown to be significantly different between groups were further analysed by Tukey's pairwise comparison tests. Mean values were calculated for all data and are presented with their standard error of the mean (S.E.M.).

\section{Results}

\section{Uterine morphology and uterine weights}

The uteri from control and progesterone-treated possums were paler in colour than those from animals treated with oestradiol or oestradiol plus progesterone. Uteri from oestradiol-treated animals were highly vascularised, but were not significantly heavier than those from either anoestrous control or progesterone-treated animals (Table 1). Uteri from oestradiol plus progesterone-treated possums were vascularised and swollen and significantly heavier than those from all other groups $(P<0.001)$.

\section{Microscopic morphology and immunohistochemistry}

\section{Control tissues}

Uterine tissue from the female mouse (positive control) had PR-positive staining in most myometrial and stromal cells. Some gland cells were also positive for PR. Luminal epithelial cells were predominantly negative for PR. All mouse and possum uterine sections that did not have antibody applied, or which were treated with goat serum in place of the antibody, stained negatively for PR (Fig. 1a).

\section{Vehicle-treated control animals}

The uterine mucosa was folded and lined by cuboidal or low-columnar epithelial cells. The underlying glands were round or oval in shape, and were also composed of cuboidal or low-columnar epithelial cells. The lumina of glands were small and clear of material. The surrounding stromal layer was dense, with fibroblastic cells tightly packed together and small blood vessels lying directly beneath the luminal epithelium. By TEM, the cuboidal and lowcolumnar luminal and glandular epithelial cells were seen to have large invaginated nuclei (Fig. 2) and only a few swollen organelles, electron lucid vesicles (ELV) and lipid droplets. A single cilium was seen in one cell only. Lysosome-like granules were observed within the basal region of these cells. Mast cells were present in the luminal epithelial layer, or immediately below it. Within the glands,

Table 1 Means \pm S.E.M. uterine weight, plasma progesterone and oestradiol concentrations and uterine cell dimensions in seasonally anoestrous brushtail possums following a 6-day period of treatment with oestradiol, progesterone, oestradiol followed by progesterone or the oil vehicle alone.

\begin{tabular}{lcccc}
\hline & Vehicle & Oestradiol & Progesterone & Oestradiol plus progesterone \\
\hline Uterine weight $(\mathrm{g} / \mathrm{kg})$ & $0.12 \pm 0.04^{\mathrm{a}}$ & $0.24 \pm 0.07^{\mathrm{a}}$ & $0.11 \pm 0.02^{\mathrm{a}}$ & $0.58 \pm 0.04^{\mathrm{b}}$ \\
Progesterone concentration $(\mathrm{ng} / \mathrm{ml})$ & $0.73 \pm 0.17^{\mathrm{a}}$ & $0.74 \pm 0.15^{\mathrm{a}}$ & $2.99 \pm 0.43^{\mathrm{b}}$ & $3.44 \pm 0.46^{\mathrm{b}}$ \\
Oestradiol concentration $(\mathrm{pg} / \mathrm{ml})$ & $9.6 \pm 1.3^{\mathrm{a}}$ & $35.3 \pm 3.7^{\mathrm{b}}$ & $12.5 \pm 2.3^{\mathrm{a}}$ & $12.7 \pm 2.4^{\mathrm{a}}$ \\
Uterine cell dimensions & & & \\
$\quad$ Luminal epithelial volume $\left(\mu \mathrm{m}^{3}\right)$ & $186.0 \pm 51.40^{\mathrm{a}}$ & $2024.2 \pm 197.75^{\mathrm{b}}$ & $226.6 \pm 2.37^{\mathrm{a}}$ & $1805.3 \pm 215.52^{\mathrm{b}}$ \\
Glandular epithelial volume $\left(\mu \mathrm{m}^{3}\right)$ & $307.5 \pm 36.80^{\mathrm{a}}$ & $1358.1 \pm 361.42^{\mathrm{b}}$ & $250.8 \pm 31.03^{\mathrm{a}}$ & $3600.4 \pm 478.02^{\mathrm{c}}$ \\
Luminal epithelial cell height $(\mu \mathrm{m})$ & $10.5 \pm 0.40^{\mathrm{a}}$ & $20.2 \pm 1.47^{\mathrm{b}}$ & $7.8 \pm 0.90^{\mathrm{a}}$ & $22.5 \pm 0.58^{\mathrm{b}}$ \\
Glandular epithelial cell height $(\mu \mathrm{m})$ & $8.6 \pm 0.50^{\mathrm{a}}$ & $26.0 \pm 1.68^{\mathrm{b}}$ & $8.1 \pm 0.32^{\mathrm{a}}$ & $27.7 \pm 2.27^{\mathrm{b}}$ \\
\hline
\end{tabular}

Within rows, means with different superscripts are significantly different: a versus b $P<0.001$; b versus c $P<0.05$. 
(a)

(c)
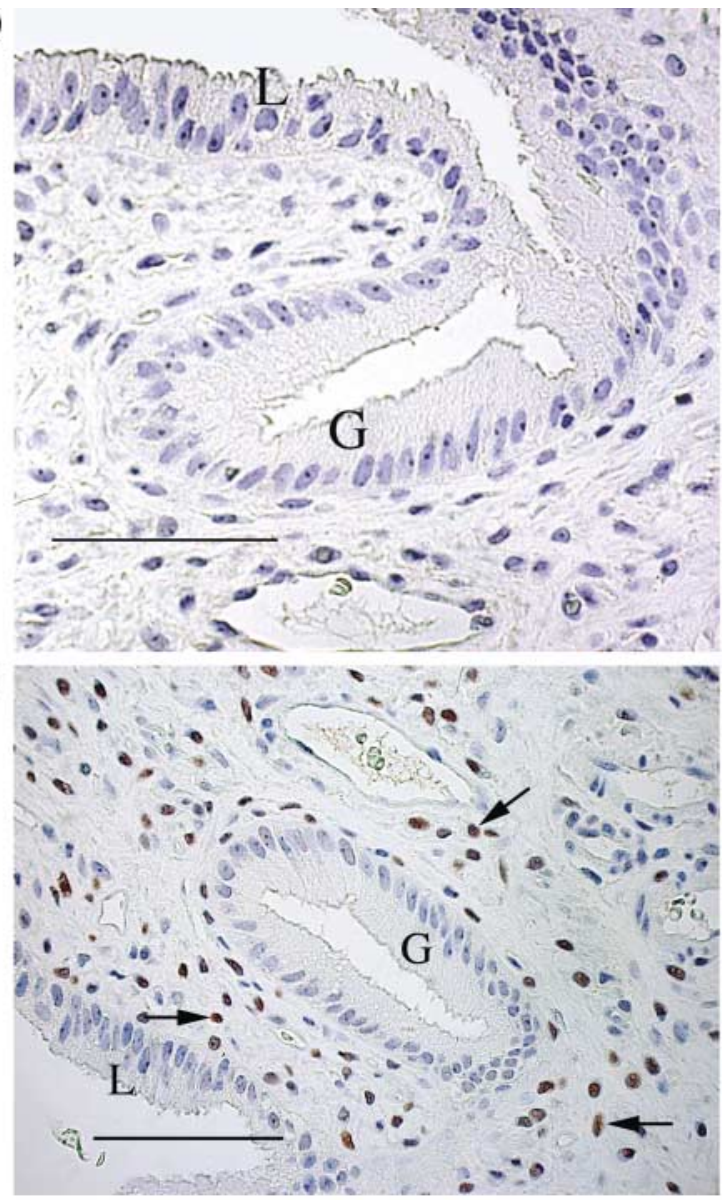

(b)

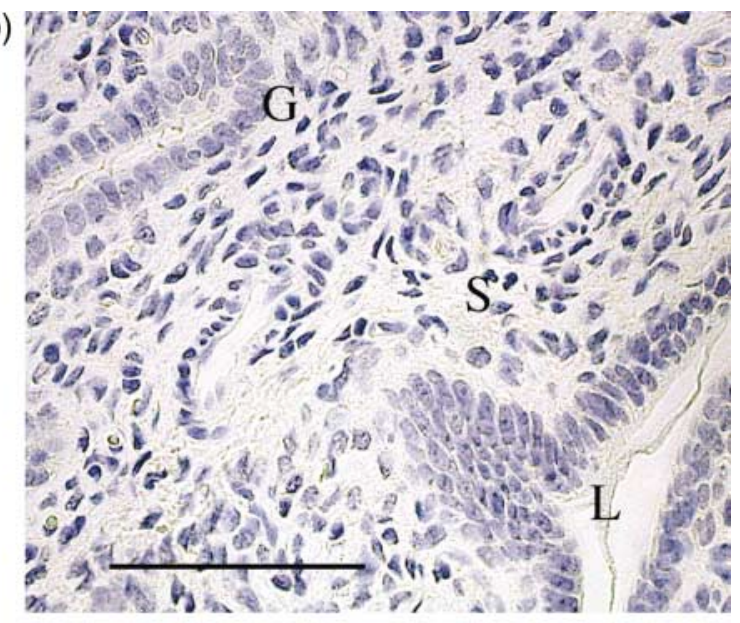

(d)

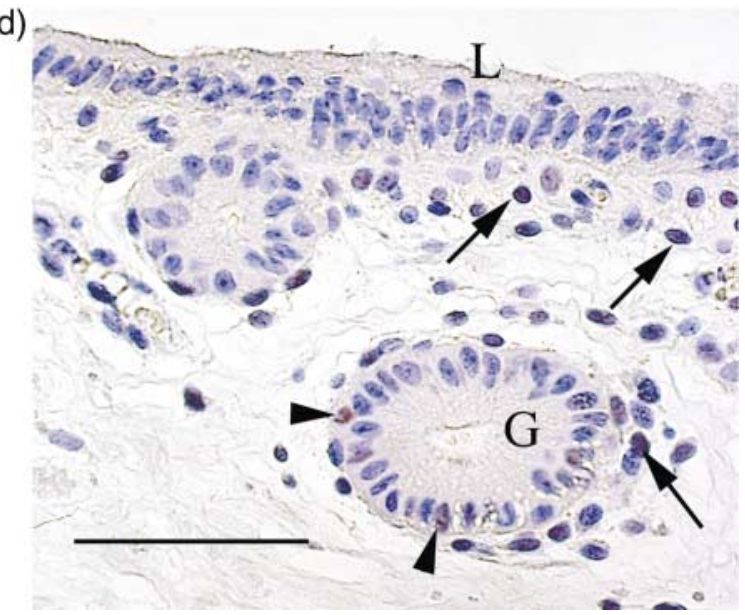

Figure 1 Immunolocalisation of PR in uterine tissue sections in possums. In (a) the section was treated with goat serum instead of the antibody. Antibody-treated sections are shown at anoestrus (b) and after treatment with implants containing oestradiol alone (c) or oestradiol plus progesterone (d). No staining is seen in (a) and (b). In (c) and (d) some stromal nuclei show red staining (arrows) and in (d) some gland epithelial nuclei are also positively stained (arrowhead). G, glandular; L, luminal epithelium; S, stromal tissue. Scale bars $=100 \mu \mathrm{m}$.

epithelial cells had distinct tight-junctional belts at the apical cell surface.

In the sections used for immunohistochemistry, none of the cell types examined showed any staining for PR (Fig. 1b).

\section{Oestradiol-treated animals}

The mucosal epithelium was folded and consisted of tall-columnar cells with a prominent brush border. The histology of the underlying glandular epithelium was similar to luminal epithelial cells and secretory vesicles were discernible. The glands themselves were large and had dilated lumina, some of which contained secretory product and fragments of cell nuclei. The stroma was oedematous and blood vessels were large by comparison with those in the uteri of the vehicle-treated group. Under TEM, both glandular and luminal cells had many microvilli and both ELV and electron dense vesicles (EDV) were abundant in the luminal epithelia. Cilia were occasionally seen in luminal epithelial cells in which basal bodies were well developed. Some pale cytoplasmic luminal epithelial cells had no apical plasma membrane and appeared to be in the process of expelling secretory vesicles and other organelles from their apical surfaces into the uterine lumen (Fig. 3). In these animals, gland lumina often contained secretory vesicles as well as cytoplasmic contents and isolated nuclei, and some glandular epithelial cells appeared degenerate and contained pale vesicles, condensed nuclei, swollen organelles and cell debris.

Approximately $20 \%$ of luminal epithelial cell nuclei stained for PR, whereas most profiles of glandular epithelium did not stain. Between $40 \%$ and $70 \%$ of stromal cells in the sub-epithelial layer stained positively (Fig. 1c). In the deeper stromal tissues, stained nuclei were observed in approximately $50 \%$ of fibroblastic cells including those in a peri-glandular location (Fig. 1c). 


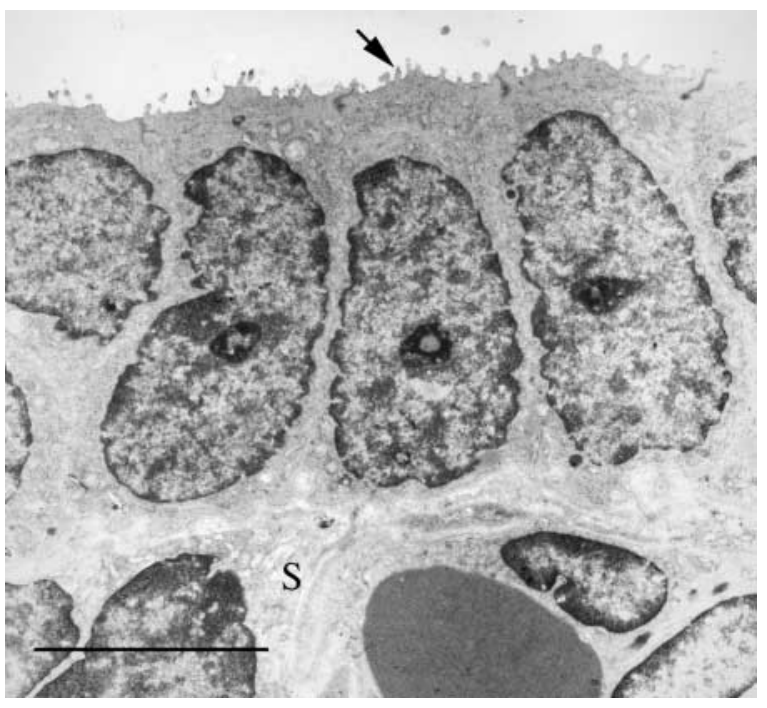

Figure 2 Electron micrograph of luminal epithelium showing closely packed cells with short microvilli (arrow). S, stroma. Scale bar $=5 \mu \mathrm{m}$.

\section{Progesterone-treated animals}

Histologically, the tissue was similar to that in vehicletreated animals (Fig. 1b). The uterine lumen was bordered by a slightly folded mucosa and lined by cuboidal or lowcolumnar cells. The underlying glands had microscopic profiles consisting of six to twelve cuboidal or low-columnar epithelial cells surrounded by small blood vessels. The stroma contained closely-packed cell nuclei and large blood vessels were present in the deep connective tissue. With TEM, luminal and glandular epithelial cells were morphologically similar to those in the vehicle-treated group. However, lysosomes or lypofuscin granules were

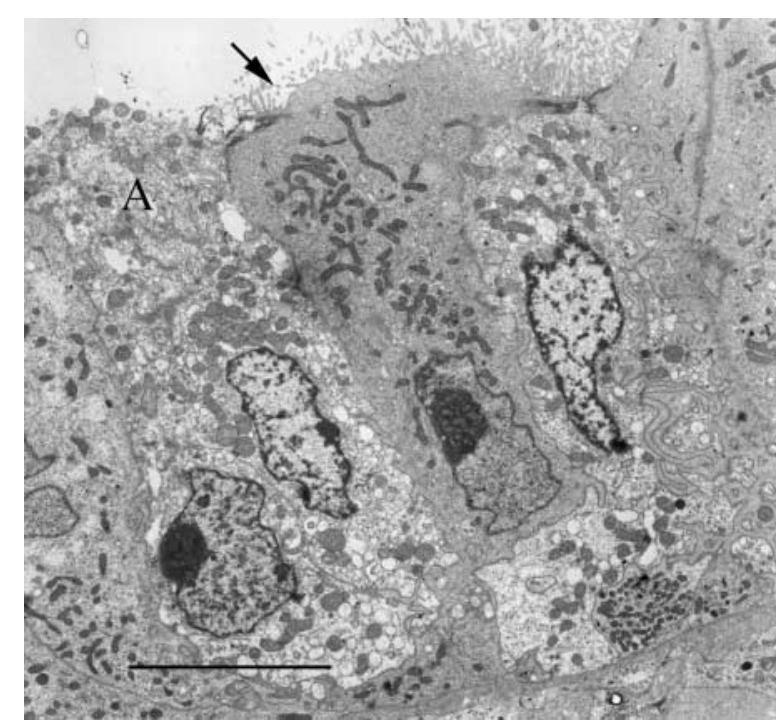

Figure 3 Electron micrograph of luminal epithelium in an oestradioltreated possum. The cell at A has no apical membrane and profiles of swollen or vesicular organelles. The arrow indicates microvilli on the surface of an adjacent healthy cell. Scale bar $=10 \mu \mathrm{m}$. observed adjacent to epithelial cells that had pale-staining cytoplasm (Fig. 4). Short microvilli were present on the apical cell surface of luminal epithelial cells, while the apical cell surface of some glandular cells lacked a plasma membrane, and gland lumina contained cell debris and/or secretory material. No cilia were observed in this group.

Neither the cytoplasm nor nuclei of luminal epithelium and glands stained for PR. With the exception of $<5 \%$ of cells with stained nuclei, stromal cells were negative for PR.

\section{Oestradiol plus progesterone-treated animals}

The mucosa was folded and lined by tall-columnar cells with a prominent brush border. Some cells were similar to the 'clear cells' described by Shorey \& Hughes (1973) and the 'void shells' in the possum cul-de-sac (Crawford et al. 1999), in that they were devoid of cytoplasmic detail and staining with only a nucleus being discernible. The underlying glands were large, consisting of columnar cells that were filled with secretory vesicles. Glands were extensive and, near the mucosal surface, gland lumina appeared to be maximally dilated, while lumina in the deeper regions were smaller. Some gland lumina contained lipid-like secretory product and these appeared throughout the glandular layer. Stromal cells were widely dispersed. By TEM, the columnar epithelial cells were generally similar to those seen in the oestradiol-only group. However, ciliated cells were more frequently seen and the EDVs were located in a basal rather than an apical position (Fig. 5). Glandular profiles also showed ciliation and here the luminal contents contained secretory product only. Some stromal and glandular epithelial cells, particularly under the luminal epithelium, stained for nuclear PR,

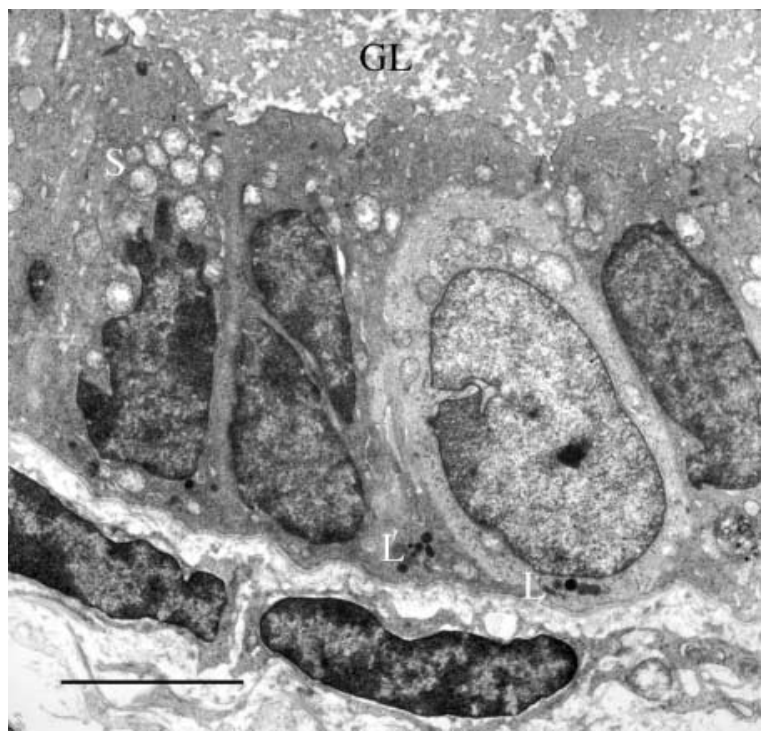

Figure 4 Electron micrograph of glandular epithelium in a progesterone-treated possum. GL, gland lumen; L, lipofuscin granules or lysosomes in the basal aspect of some cells; S, secretory vesicles. Scale bar $=5 \mu \mathrm{m}$. 


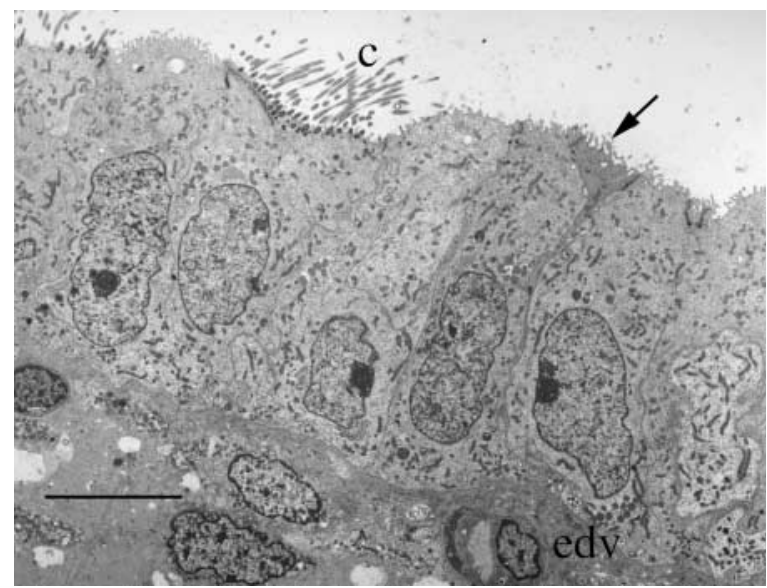

Figure 5 Electron micrograph of luminal epithelium in an animal treated with both oestradiol and progesterone. Cilia (C) and microvilli (arrow) are prominent. edv, areas where electron dense vesicles are present in the basal aspect of epithelial cells. Scale bar $=10 \mu \mathrm{m}$.

whereas the luminal epithelium was negative for nuclear PR (Fig. 1d). Some positive-staining nuclei were observed in and around the base of glands. The number of positively stained stromal cells was approximately 30\% less than that observed in animals treated with oestradiol alone.

\section{Plasma hormone concentrations}

Mean plasma progesterone concentrations were significantly higher $(<3.0 \mathrm{ng} / \mathrm{ml}, P<0.001)$ in animals treated with either progesterone alone or oestradiol and then progesterone, than in animals treated with either oestradiol or the oil vehicle $(<0.8 \mathrm{ng} / \mathrm{ml})$. Oestradiol concentrations were significantly higher $(P<0.001)$ in oestradiol-treated possums than in the other three groups (Table 1).

\section{Stereology}

For both luminal and glandular epithelial cells, mean cell heights and volumes were not significantly different between control and progesterone-treated animals, but were greater $(P<0.001)$ in oestradiol and oestradiol plus progesterone-treated possums. In addition, the mean volume (but not cell height) of both luminal and glandular epithelial cells was greater $(P<0.05)$ in animals treated with oestradiol plus progesterone than in those treated with oestradiol alone (Table 1). Volumes of cellular constituents (nuclei, mitochondria, secretory vesicles and cytoplasm) for both luminal and glandular epithelium were also greater in animals treated with oestradiol and oestradiol plus progesterone.

\section{Discussion}

The mean uterine weights and gross morphological changes in uterine tissues recorded in this study were similar to those reported in naturally cycling possums (Shorey \& Hughes 1972, 1973, Curlewis \& Stone 1986, Crawford et al. 1997). Namely, uterine weights of control anoestrous possums, oestradiol-treated and oestradiol/progesterone-treated possums were comparable with those of animals at the time of pouch young removal, in the late follicular phase and early luteal phase, respectively (Curlewis \& Stone 1986, Crawford et al. 1997). Treatment with oestradiol alone induced some tissue growth, whereas progesterone alone caused some vascularisation and swelling of uterine tissues. This confirms the different effects that these ovarian steroids have on possum uterine tissue, supporting the notion that oestradiol is required to prime the uterus in preparation for the action of progesterone, as has been hypothesised for eutherian animals (see Brenner \& West 1975 for review). Furthermore, the LM appearance of the possum uterus after oestradiol plus progesterone treatment was similar to the gravid endometrium of the dunnart at day 8 after mating (Cruz \& Selwood 1997).

The regional variation in gland dilation observed in oestradiol/progesterone-treated tissue (i.e. lumina with the greatest dilation in the upper middle region of the glands) may indicate a greater secretory capacity of glands in these regions. Such glandular dilation may reflect the importance of uterine secretion (Shorey \& Hughes 1972, 1973) as the morphology of glands from animals treated with oestradiol plus progesterone is consistent with that reported to occur at day 16 of the oestrous cycle in naturally cycling possums (Shorey \& Hughes 1975).

To our knowledge, there have been no previous immunohistochemical studies of PRs in possum tissue. In general, the findings of the present study agree with those of Vermeirsch et al. $(2000 a, b)$ for steroid receptors in canine uterine tissue. In the brushtail possum, PRs were always located in the cell nuclei, as was the case for the dog. Curlewis \& Stone (1986) reported PR concentrations in cytosol from uterine cells of the possum. However, that method would have included PR of nuclear origin in the cytosol preparation.

There were more cells positive for PR in uteri of possums treated with oestradiol than in those treated with both oestradiol and progesterone. This supports the theory that oestradiol generally causes an increase in nuclear PR formation as previously reported in primates (Brenner et al. 1990), dogs (Vermeirsch et al. 2000a,b) and for cytoplasmic PRs in the quokka uterus (Owen et al. 1982). The reduction in PR numbers in oestradiol/progesterone-treated possums suggests that progesterone causes the down-regulation of its own receptors as has been postulated to occur in other species (Brenner et al. 1990). Although the mechanism by which progesterone down-regulates its own receptors is yet to be described, it has been hypothesised that the progesterone-receptor complex relocates to the nucleus and subsequently degenerates (Milgrom et al. 1973). It is also possible that progesterone binding may block subsequent antibody-receptor binding. The cells 
that most frequently stained positive for PR were stromal cells (excluding myometrial cells, which were not examined in this study).

The dominant vesicle type observed in possums treated with oestradiol or with both oestradiol and progesterone was ELVs. Similar vesicles have also been observed in the cul-de-sac epithelia of possums (Crawford et al. 1999) and endometria of guinea pigs (Larkin et al. 1987) and sheep (Murray 1992). It is likely that these vesicles were produced through an oestradiol-dependent mechanism and that they contain mucus-like carbohydrates. Crawford et al. (1999) suggested that this may have a role in sperm survival, storage or capacitation in the possum cul-de-sac. It is possible they may have similar functions in the uterus. These secretory vesicles may also contain proteins important in thickening the egg shell membrane of marsupials, as suggested by both Hughes (1974) and Shaw (1996). ELVs have been commonly seen in various other animal species following treatment with either oestradiol or progesterone after oestradiol (Larkin et al. 1987). EDVs have been observed in the cul-de-sac of the possum and in the uterus of the cat, pig and sheep (Li et al. 1992, Murray 1992, Geisert et al. 1997, Crawford et al. 1999).

Other secretory products produced under the influence of progesterone include glycogen and glycoproteins which are thought to cause the gland dilation that is observed in oestradiol/progesterone-treated tissue (Good \& Moyer 1968). In guinea pigs, relaxin, the hormone responsible for preparation of the myometrium for parturition, is produced in response to sequential oestradiol and progesterone treatment (Larkin et al. 1987). In summary, there are many secretory products formed under the influence of oestradiol and oestradiol/progesterone, some or all of which may occur in the two secretory vesicle types observed in the uterus of the brushtail possum and contribute to the production of uterine secretions.

Large numbers of cilia and microvilli were seen in tissue from both the oestradiol and oestradiol/progesterone-treated possums and were similar to those reported in cyclic animals (Arnold \& Shorey 1985). The contrasting diminished numbers of cilia in the vehicle- and progesterone-treated groups gives support to the idea that oestradiol is a significant factor in possum ciliogenesis as also indicated in primate oviduct (Verhage et al. 1990). Microvilli were longer and more highly organised in animals treated with oestradiol only and shorter and disorganised in oestradiol plus progesterone-treated possums, as has been observed in humans and rabbits (Johannisson \& Nilsson 1972, Masterton et al. 1975). The disruption in microvilli integrity, as seen in oestradiol plus progesterone-treated possums is thought to be due to exocytosis of secretory vesicles (Bareither \& Verhage 1980). Thus, the appearance of microvilli may occur in order to increase the surface area of the cell to aid in secretion as has been shown to occur in other secretory cells. The short microvilli of anoestrous possum uteri agrees with the observations of
Arnold \& Shorey (1985), who suggested that this was due to the absence of oestradiol.

Often both luminal and glandular epithelial cells had dissimilarly staining cytoplasm when viewed by TEM and this occurred in all treatment groups. Similar observations have been reported to occur in the cul-de-sac tissue of possums (Crawford et al. 1999), where paler staining cells were found to occur in conjunction with adjacent mast cells (Crawford et al. 1999). In the present study, mast cells were found more frequently in vehicle- and progesterone-treated groups, whereas paler staining cells were found in all groups. Shorey \& Hughes (1973) observed pale cytoplasmic cells at both LM and EM levels, which agrees with observations in this current study. As described, at the LM level, pale cells were the same as those that Crawford et al. (1999) referred to as void shells in the brushtail possum cul-de-sac. It was concluded that the pale cytoplasmic cells were, in fact, ciliated cells and darker cytoplasmic cells were non-ciliated or secretory cells (Shorey \& Hughes 1973). Alternatively, differently stained cytoplasm may indicate that cells are in different metabolic states. Paler cells may be degenerating or dying. Cell death is a common occurrence in the endometria of many species and is thought to be a continuous process of cell turnover. It also accounts for the changing proportions in ciliated and secretory cells reported in possums (Arnold \& Shorey 1985). In the current study, cells that appeared to be dying were observed in the luminal epithelium in oestradiol-treated animals and in the glandular epithelium in oestradiol/progesterone-treated animals.

Cell debris, including degenerating nuclei, was seen in the lumina of glands, mainly in oestradiol-treated tissue. Features associated with the debris and the putative dying cells in this study are similar to those reported in dying uterine cells in hamsters (Sandow et al. 1979). In theory, dying cells could expel their cellular contents into an adjacent lumen (uterine or glandular), leaving an empty shell as reported in cul-de-sac tissue (Crawford et al. 1999). The cell debris observed here in the gland lumina of the oestradiol-treated animals may also have been a consequence of holocrine secretion or cellular degeneration in preparation for gland regeneration. Shorey \& Hughes $(1972,1973)$ observed glands during pro-oestrus in which the outer region was considered to have been formed recently from adjacent stromal tissue. The inner layer of the gland consisted of degenerate cell debris similar to that described here. From this study, it was concluded that oestradiol induced cellular growth, which continued after progesterone was administered. Progesterone caused full maturation of the tissue and active secretion.

This study used anoestrous possums implanted with steroid hormones to simulate the effects of oestradiol and progesterone on the uterus. Whilst this model may not have accurately mimicked the events in naturally cycling animals, it does show, separately and sequentially, the hormonal actions of oestradiol and progesterone on the 
uterus of the brushtail possum. Obvious shortcomings of the model are the occurrence of abrupt changes in steroid hormone concentrations, rather than the progressive changes that occur during the oestrous cycle, and likely differences in gonadotrophin hormone secretion.

\section{Acknowledgements}

We thank Euan Thompson, AgResearch Invermay, for care of the animals and expert assistance with tissue collection and Bronwyn Smaill, South Campus EM Unit, for her invaluable assistance with TEM.

\section{References}

Arnold R \& Shorey CD 1985 Structure of the uterine luminal epithelium of the brush-tailed possum (Trichosurus vulpecula). Journal of Reproduction and Fertility 74 565-573.

Baddeley AJ, Gundersen HJG \& Cruz-Orive LM 1986 Estimation of surface area from vertical sections. Journal of Microscopy 142 259-276.

Bareither ML \& Verhage HG 1980 Effect of estrogen and progesterone on secretory granule formation and release in the endometrium of the ovariectomized cat. Biology of Reproduction 22 635-643.

Brenner RM \& West NB 1975 Hormonal regulation of the reproductive tract in female mammals. Annual Review of Physiology $\mathbf{3 7}$ 273-293.

Brenner RM, West NB \& McClellan MC 1990 Estrogen and progestin receptors in the reproductive tract of the male and female primates. Biology of Reproduction 42 11-19.

Conneely OM, Mulac-Jericevic B, DeMayo F, Lydon JP \& O'Malley BW 2002 Reproductive functions of progesterone receptors. Recent Progress in Hormone Research 57 339-355.

Crawford JL, Shackell GH, Thompson EG, McLeod BJ \& Hurst PR 1997 Preovulatory follicle development and ovulation in the brushtail possum (Trichosurus vulpecula) monitored by repeated laparoscopy. Journal of Reproduction and Fertility $110361-370$.

Crawford JL, McLeod BJ \& Hurst PR 1999 Cyclical changes in epithelial cells of the vaginal cul-de-sac of brushtail possums (Trichosurus vulpecula). Anatomical Record 254 307-321.

Cruz YP \& Selwood L 1997 Histological differences between gravid and non-gravid uteri in the dasyurid marsupial, Sminthopsis macroura (Spencer). Journal of Reproduction and Fertility 111 $319-325$.

Curlewis JD \& Stone GM 1986 Effects of oestradiol, the oestrous cycle and pregnancy on weight, metabolism, and cytosol receptors in the uterus of the brush-tail possum (Trichosurus vulpecula). Journal of Endocrinology 108 201-210.

Geisert RP, Blair RM, Pratt T \& Zavy MT 1997 Characterization and proteolytic activity of a cathepsin L-like polypeptide in endometrium and uterine flushings of cycling, pregnant and steroid-treated ovariectomized gilts. Reproduction, Fertility and Development 9 395-402.

Good RG \& Moyer DL 1968 Estrogen-progesterone relationships in the development of secretory endometrium. Fertility and Sterility $1937-49$.

Gundersen HJG \& Jensen EB 1983 Particle sizes and their distributions estimated from line- and point-sampled intercepts, including graphical unfolding. Journal of Microscopy 131 291-310.

Gundersen HJ, Bagger P, Bendtsen TF, Evans SM, Korbo L, Marcussen $\mathbf{N}$ et al. 1988 The new stereological tools; disector, fractionator, nucleator and point sampled intercepts and their use in pathological research and diagnosis. APMIS 91 857-881.

Hughes RL 1974 Morphological studies on implantation in marsupials. Journal of Reproduction and Fertility 39 173-186.
Johannisson E \& Nilsson L 1972 Scanning electron microscopic study of the human endometrium. Fertility and Sterility 23 613-625.

Kean RI, Marryatt RG \& Carroll ALK 1964 The female urogenital system of Trichosurus vulpecula (Marsupialia). Australian Journal of Zoology 12 18-41.

Larkin LH, Ogilvie S, Wubel L \& Welch DE 1987 Effects of estradiol and progesterone on accumulation of relaxin- and carbohydratecontaining granules in endometrial gland cells of the guinea pig. American Journal of Anatomy 179 333-341.

Lessey BA, Killam AP, Metzger DA, Haney AF, Greene GL \& McCarty KS 1988 Immunohistochemical analysis of human uterine estrogen and progesterone receptors throughout the menstrual cycle. Journal of Clinical Endocrinology and Metabolism 67 334-339.

Li W, Jaffe RC \& Verhage HG 1992 Immunocytochemical localization and messenger ribonucleic acid levels of a progesteronedependent endometrial secretory protein (cathepsin L) in the pregnant cat uterus. Biology of Reproduction 47 21-28.

Lun S, Smith P, Lundy T, O'Connell A, Hudson N \& McNatty KP 1998 Steroid contents of steroidogenesis in vitro by the developing gonad and mesonephros around sexual differentiation in fetal sheep. Journal of Reproduction and Fertility 114 131-139.

McLeod BJ, Thompson EG, Crawford JL \& Shackell GH 1997 Successful group housing of wild-caught brushtail possums (Trichsosurus vulpecula). Animal Welfare 6 67-76.

McLeod BJ, Thompson EG \& Crawford JL 1999 Synchrony of onset and cessation of breeding activity in brushtail possums (Trichosurus vulpecula) in coastal Otago. Proceedings of the New Zealand Society of Animal Production 59 229-232.

Mahoney PM, Hurst PR, McLeod BJ \& McConnell MA 2002 Quantification of mast cells and microflora in the cul-de-sac of the brushtail possum (Trichosurus vulpecula). Reproduction 124 399-408.

Mahoney PM, Hurst PR, McLeod BJ \& McConnell MA 2003 The effect of oestradiol treatment on mast cell populations and microflora in the vaginal cul-de-sac of seasonally anoestrous brushtail possums (Trichosurus vulpecula). Reproduction $125733-741$.

Masterton R, Armstrong EM \& More IAR 1975 The cyclical variation in the percentage of ciliated cells in the normal human endometrium. Journal of Reproduction and Fertility 42 537-540.

Milgrom E, Thi L, Atger M \& Baulieu E-E 1973 Mechanisms regulating the concentration and conformation of progesterone receptor(s) in the uterus. Journal of Biological Chemistry 248 6366-6374.

Murray MK 1992 The effect of estrogen and progesterone on structural changes in the uterine glandular epithelium of the ovariectomized sheep. Biology of Reproduction 47 408-417.

Nelson KG, Takahashi T, Bossert NL, Walmer DK \& McLachlan JA 1991 Epidermal growth factor replaces estrogen in the stimulation of female genital-tract growth and differentiation. PNAS 88 21-25.

Owen FJ, Cake MH \& Bradshaw SD 1982 Characterization and properties of a progesterone receptor in the uterus of the quokka (Setonix brachyurus). Journal of Endocrinology 93 17-24.

Pekonen P, Partanen S, Makinen T \& Rutanen EM 1988 Receptors for epidermal growth factor and insulin-like growth factor I and their relation to steroid receptors in human breast cancer. Cancer Research 48 1343-1347.

Pilton PE \& Sharman GB 1962 Reproduction in the marsupial. Trichosurus vulpecula. Journal of Endocrinology 25 119-136.

Renfree MB \& Blanden DR 2000 Progesterone and oestrogen receptors in the female genital tract throughout pregnancy in tammar wallabies. Journal of Reproduction and Fertility 119 121-128.

Sandow BA, West NB, Norman RL \& Brenner RM 1979 Hormonal control of apoptosis in hamster uterine luminal epithelium. Journal of Anatomy 156 15-36.

Saunders PT 1998 Oestrogen receptor beta (ER beta). Reviews of Reproduction 3 164-171. 
Shaw G 1996 The uterine environment in early pregnancy in the tammar wallaby. Reproduction, Fertility and Development 8 $811-818$.

Shorey CD \& Hughes RL 1972 Uterine glandular regeneration during the follicular phase in the marsupial Trichosurus vulpecula. Australian Journal of Zoology 20 235-247.

Shorey CD \& Hughes RL 1973 Cyclical changes in the uterine endometrium and peripheral plasma concentrations of progesterone in the marsupial Trichosurus vulpecula. Australian Journal of Zoology $211-19$.

Shorey CD \& Hughes RL 1975 Uterine response to ovariectomy during the proliferative and luteal phases in the marsupial Trichosurus vulpecula. Journal of Reproduction and Fertility $\mathbf{4 2}$ $221-228$.

Tyndale-Biscoe CH 1984 Reproductive physiology of possums and gliders. In Possums and Gliders, pp 79-89. Eds AP Smith \& ID Hume. Australia: Surrey Beatty \& Sons Pty Limited.

Verhage HG, Mavrogianis PA, Boice ML, Li W \& Fazleabas AT 1990 Oviduct epithelium of the baboon: hormonal control and the immuno-gold localization of oviduct-specific glycoproteins. American Journal of Anatomy 187 81-90.
Vermeirsch H, Simoens P \& Lauwers H 2000a Immunohistochemical detection of estrogen receptor- $\alpha$ and progesterone receptor in the canine pregnant uterus and placental labyrinth. Anatomical Record $26042-50$.

Vermeirsch H, Simoens P, Hellemans A, Coryn M \& Lauwers H $2000 \mathrm{~b}$ Immunohistochemical detection of progesterone receptors in the canine uterus and their relation to sex steroid hormone levels. Theriogenology 53 773-778.

Zeps N, Bentel JM, Papadimitriou JM \& Dawkins HJS 1999 Murine progesterone receptor expression in proliferating mammary epithelial cells during normal pubertal development and adult estrous cycle: association with ER $\alpha$ and ER $\beta$ status. Journal of Histochemistry and Cytochemistry 47 1323-1330.

Received 24 March 2003

First decision 23 May 2003

Revised manuscript received 3 Novemebr 2003

Accepted 6 November 2003 